\title{
Using lidar to assess the development of structural diversity in forests undergoing passive rewilding in temperate Northern Europe
}

\author{
Henrik Thers ${ }^{\text {Corresp., }}{ }^{1,2}$, Peder Klith Bøcher ${ }^{1}$, Jens-Christian Svenning ${ }^{1}$ \\ 1 Department of Bioscience, Aarhus University, Aarhus, Denmark \\ 2 Department of Agroecology, Aarhus University, Tjele, Denmark \\ Corresponding Author: Henrik Thers \\ Email address: thers@agro.au.dk
}

Forested areas are increasing across Europe, driven by both reforestation programs and farmland abandonment. While tree planting remains the standard reforestation strategy, there is increased interest in spontaneous regeneration as a cost-effective method with equal or potentially greater benefits. Furthermore, expanding areas of already established forests are left for passive rewilding to promote biodiversity conservation. Effective and objective methods are needed for monitoring and analyzing the development of forest structure under these management scenarios, with airborne laser scanning (lidar: Light Detection And Ranging) being a promising methodology.

Here we assess the structural characteristics and development of unmanaged forests and 28- to 78-year old spontaneously regenerated forests on former agricultural land, relative to managed forests of similar age in Denmark, using 25 lidar-derived metrics in 10-m and 30-m grid cells. We analyzed the lidarderived cell values in a Principal Component Analysis (PCA) and interpreted the axes ecologically, in conjunction with pairwise tests of median and variance of PCA-values for each forest.

Spontaneously regenerated forest in general had increased structural heterogeneity compared to planted and managed forests. Furthermore, structural heterogeneity kept increasing in spontaneously regenerated forest across the maximal 78-year timespan investigated. Natural disturbances showed strong impacts on vegetation structure, leading to both structural homogeneity and heterogeneity. The results illustrate the utility of passive rewilding for generating structurally heterogeneous forested nature areas, and the utility of lidar surveys for monitoring and interpreting structural development of such forests. 
1 Using lidar to assess the development of structural diversity in

2 forests undergoing passive rewilding in temperate Northern

3

Europe

4

5 Henrik Thers ${ }^{1,2}$, Peder Klith Bøcher ${ }^{1}$, Jens-Christian Svenning ${ }^{1}$

61 Department of Bioscience, Aarhus University, Aarhus, Denmark

72 Current affiliation: Department of Agroecology, Aarhus

8 University, Tjele, Denmark

9 Corresponding Author:

10 Henrik Thers ${ }^{1,2}$

11 Email address: henrikthers@yahoo.dk 


\section{Abstract}

14 Forested areas are increasing across Europe, driven by both

15 reforestation programs and farmland abandonment. While tree

16 planting remains the standard reforestation strategy, there is

17 increased interest in spontaneous regeneration as a cost-

18 effective method with equal or potentially greater benefits.

19 Furthermore, expanding areas of already established forests are

20 left for passive rewilding to promote biodiversity conservation.

21 Effective and objective methods are needed for monitoring and

22 analyzing the development of forest structure under these

23 management scenarios, with airborne laser scanning (lidar: Light

24 Detection And Ranging) being a promising methodology.

Here we assess the structural characteristics and

26 development of unmanaged forests and 28- to 78-year old

27 spontaneously regenerated forests on former agricultural land,

28 relative to managed forests of similar age in Denmark, using 25

29 lidar-derived metrics in 10-m and 30-m grid cells. We analyzed

30 the lidar-derived cell values in a Principal Component Analysis

31 (PCA) and interpreted the axes ecologically, in conjunction with

32 pairwise tests of median and variance of PCA-values for each

33 forest.

Spontaneously regenerated forest in general had

35 increased structural heterogeneity compared to planted and

36 managed forests. Furthermore, structural heterogeneity kept 
37

38

increasing in spontaneously regenerated forest across the maximal 78-year timespan investigated. Natural disturbances showed strong impacts on vegetation structure, leading to both structural homogeneity and heterogeneity. The results illustrate the utility of passive rewilding for generating structurally heterogeneous forested nature areas, and the utility of lidar surveys for monitoring and interpreting structural development of such forests.

\section{Introduction}

Forest structure is important for biodiversity, notably via providing heterogeneous environments in terms of available resources and structural composition (Simonson, Allen, \& Coomes, 2014; Stein, Gerstner, \& Kreft, 2014; Tews et al., 2004). Commercially and intensively managed forests often show less structural heterogeneity compared to unmanaged forests due to establishment strategy (planted as even-aged monocultures or naturally regenerated as fenced stands without gaps), and due to prevention of natural dynamics (harvesting the biologically young trees, by drainage, thinning and pest control) 
59 (Christensen \& Emborg, 1996; Nielsen \& Jensen, 2007; Richnau, 60 Wistrom, \& Nielsen, 2012). The homogeneous structure of

61 deciduous temperate forests under traditional silvicultural

62 management has put a wide range of forest-associated species at 63 risk, affecting both fungi, animals and plants (Christensen \& 64 Emborg, 1996; Hofmeister, Hosek, \& Brabec, 2015; Ishii, Tanabe, 65 \& Hiura, 2004). Hence, one relevant aim for forest restoration 66 is to facilitate the development of more heterogeneous forest 67 structure than seen in managed forests (Götmark, 2013). Passive 68 rewilding, defined as spontaneous ecological dynamics without 69 management (Svenning et al., 2015), is one restoration strategy 70 that is thought to lead to more heterogeneous forests compared 71 to managed forests. Pathways toward forests under passive 72 rewilding can be: 1. Ceasing the silvicultural management of 73 existing forests and 2. Natural regeneration of new forest 74 areas, e.g. on abandoned farmland (Schnitzler, 2014). Forest cover in Europe is increasing due to active 76 reforestation as well as abandonment of farmland (Navarro \& 77 Pereira, 2012; Verheyen, Vanhellemont, \& Auge, 2015). In Europe, 78 between 10 and 29 million ha of agricultural land is predicted 79 to become abandoned between 2000 to 2030 (Verburg \& Overmars, 80 2009), much of it becoming available for active reforestation or 81 passive rewilding. Advantages and drawbacks of various ways of 82 forest establishment have been investigated in terms of costs, 
83 biodiversity, public opinion, carbon sequestration and other 84 ecosystem services, and natural regeneration is considered the 85 cheapest and slowest (Benayas, Bullock, \& Newton, 2008; Cramer, 86 Hobbs, \& Standish, 2008; Nielsen \& Jensen, 2007; Prach \& Pyšek, 87 2001; Verheyen et al., 2015). However, natural regeneration is 88 also the most uncertain method, with an outcome that is hard to 89 predict (Benayas et al., 2008; Bullock, Moy, \& Pywell, 2002; 90 Prach \& Pyšek, 2001; Schnitzler, 2014). Among factors 91 influencing the development of vegetation structure following 92 natural regeneration are seed supply, seed predation, 93 herbivores, abiotic site conditions (e.g. pH and soil moisture), 94 competition from herbs, non-indigenous plant species, 95 disturbance regime and former land use; factors which interact 96 in complex ways (Hobbs \& Cramer, 2007a; Nilsson, Hedin, \& 97 Niklasson, 2001; Prach \& Pyšek, 2001). In addition, the speed of 98 secondary succession varies. Long delays in succession can occur 99 due to arresting factors such as high water level, drought and 100 competition from herbs and grasses (Prach \& Pyšek, 1994; 2001). 101 Such prolonged vegetation development secures a mixture of open 102 areas and denser vegetation, which has been found to increase 103 the overall forest biodiversity (Sebek et al., 2015). 104 Consequently, the various outcomes of complex natural 105 regeneration make it difficult to optimize designs in targeting 106 the specific purpose of reforestation (Navarro \& Pereira, 2012). 
108 are more likely to be affected by natural disturbances due to 109 windfall, insects and moist conditions and have more and larger 110 dead trunks compared to managed forests (Nilsson et al., 2001). 11 The level and type of disturbance are decisive to the 112 development of forest structure (Syrjänen, Kalliola, Puolasmaa, 113 \& Mattsson, 1994), and an intermediate disturbance level is 114 believed to provide the most heterogeneous and species-rich 115 habitat (Roberts \& Gilliam, 1995). It follows that forests 116 allowed to undergo rewilding can be expected to increase 117 heterogeneity and thereby create niches available to a more 118 diverse species composition. In order to be able to advise managers on the 120 effectiveness of passive rewilding in producing structurally 121 heterogeneous forests of high value for biodiversity, along with 122 optimized management actions in the rewilding process, it is 123 necessary to monitor and evaluate the structural development of 124 vegetation left for passive rewilding. Lidar (Light Detection 125 And Ranging) data has proven to be efficient for measuring 126 forest structure on a scale relevant for biodiversity (Bässler 127 et al., 2010; Thers et al., 2017; Zellweger et al., 2016), and 128 in recent years further studies have presented lidar-based 129 methods for differentiating vegetation structure in stands of 130 varying management and site history. Valbuena et al. (2016) 
131 assessed recognition of forest structural type by ALS-based gini 132 coefficients and related the findings to management in Finnish 133 boreal stands. Ehbrecht et al. (2016) and Listopad et al. (2018) 134 measured effective numbers of forest layers in Germany and shrub 135 regeneration in Portugal, respectively, using TLS (terrestrial 136 laser scanning), and proved significant correlations to 137 traditional forestry metrics. Listopad et al. (2018) also 138 compared the findings to the site grazing history. However, 139 there is a lack of papers focusing on the use of ALS-derived 140 information to add additional information to the specific site 141 history and to interpret the findings in relation to ecological

142 theory, hereby strengthening the foundation for rewilding 143 projects.

144 We aim to use simple wall-to-wall ALS point cloud-derived 145 metrics treated by PCA (principal component analysis) to analyze 146 a unique Danish rewilding site (the 64-ha island of Vorsø) and 147 to relate the findings to the existing ecological theory of 148 natural disturbances and spontaneous vegetation development. 149 Hereby, merging a remote sensing survey and rewilding ecology 150 relevant to policy makers and managers. We do this by comparing 151 rewilded stands to managed stands of similar age, soil and 152 climatic conditions. The Vors $\varnothing$ case provides the possibility to 153 evaluate two different starting points for passive rewilding - 
154 spontaneous regeneration on abandoned farmland and the ceasing 155 of management actions in existing forests.

\section{Methods}

\section{Study sites}

158 Four localities where chosen for the examination and comparison 159 of forest structure by lidar (Fig 1, Fig. 2). The sites are 160 situated within a $900-\mathrm{km}^{2}$ area delimited by the UTM zone $32 \mathrm{~N}$ 161 coordinates: Northering: 6190000 to 6220000 and Eastering: 162550000 to 580000. The main locality was Vorsø, an island in 163 Horsens Fjord in eastern Jutland (Denmark). Vors $\varnothing$ was chosen 164 because of the unique and well-documented vegetation history 165 (Halberg and Gregersen, 2010). We divided Vorsø into seven 166 areas, hereafter named zones, according to the history of the 167 island. The zones are named with the letter $V$ for Vors $\varnothing$, 168 followed by $Y$ (young), $M$ (mid-aged) or $O$ (old) corresponding to 169 the site history (vegetation age) of the zone. The numbers $170(1,2, \ldots)$ differentiates zones and areas of similar age. Areas 171 influenced by humans, such as buildings, roads, and old gardens, 172 were excluded from the seven zones of Vors $\varnothing$.

173 Fig. 1 Site locations. (A) The geographical position of the four 174 sites (Three managed forests and Vorsø) investigated in this 175 paper marked with black stars in the eastern part of Jutland 176 (Denmark). (B) The position of Denmark in Europe (Marked with 
177 light edges). (C) The island of Vorsø; V_o1 (6.11 ha); V_02

178 (2.65 ha); V_03 (0.38 ha) (labeled below the zone); V_M1 (15.06

179 ha); V_M2 (9.09 ha); V_Y2 (5.09 ha); V_Y1 (8.89 ha). (D) The

180 extent of the Tran_Y3 oak (Quercus Robur) forest (4.51 ha). (E)

181 Fløj_Y4, the extent of the mixed maple (Acer pseudoplatanus) and

182 beech (Fagus sylvatica) forest (0.92 ha). (F) Sten_M/O, the

183 extent of the predominantly beech (Fagus Sylvatica) forest

184 (20.42 ha). A minor stand of spruce (Picea abies) is

185 recognizable as a dark area in the lower part of the forest. See 186 Fig. 2 for photos of the stands. DDOeland 2016, Copyright COWI $187 \mathrm{~A} / \mathrm{S}$.

188 Fig. 2 Photos of the managed stands and selected zones of Vors $\varnothing$.

189 (A) A representative site of the managed oak forest of Tran_Y3.

190 (B) A representative site of the managed maple and beech forest 191 of Fløj_Y4. (C) A representative site of the predominated beech 192 forest of Sten_M/O. (D) An example of the homogeneous structure 193 in the sycamore maple (Acer pseudoplatanus) -dominated eastern 194 and southern part of V_M2. Note the structural similarity to the 195 Sten_M/O forest (C). (E) The succession of the otherwise old 196 V_o2 has started over, due to the impact of cormorants 197 (Phalacrocorax carbo), and consists of scattered young trees and 198 shrubs, mainly elderberry (Sambucus nigra). (F) An example of 199 the mixed structure of scrub, gaps, large trees, and dead wood 200 only found in the V_MI. 
202 leaving the three existing forest patches (V_O1, V_O2 and V_O3)

203 and the main part of the farmland (V_M1 and V_M2) for passive

204 rewilding. The passive rewilding process of the three forests

205 were initiated by the destruction of the drainage and the

206 eradication of bigger stands of non-indigenous tree species. In

2071979 farming ceased in the remaining farmland (V_Y1 and V_Y2).

208 No management, planting or seeding actions have been performed

209 during the years of protection, although cormorants

210 (Phalacrocorax carbo) was regulated before 1979 to keep numbers

211 down. The main influencing factors since protection have been

212 tree-killing excrements from the cormorant colonies (heavy

213 impact on V_O2, and minor to medium impact on V_O1 and V_M1),

214 windfall (mainly V_O1), roe deer (Capreolus capreolus), Dutch

215 elm disease, along with heavy seed supply of sycamore maple to

216 V_M2 from V_O2 and V_O3.

217

At the time of our survey the dominant tree species

218 were oak (Quercus robur), maple (Acer pseudoplatanus), ash

219 (Fraxinus excelsior), beech (Fagus sylvatica) and elm (Ulmus

220 glabra, heavily reduced by Dutch elm disease), as well as alder

221 (Alnus glutinosa) in wet areas. Frequent occurring shrub species

222 were elderberry (Sambucus nigra), blackthorn (Prunus spinosa),

223 raspberry (Rubus idaeus), single-seeded hawthorn (Crataegus

224 monogyna), cherry plum (Prunus cerasifera), dog rose (Rosa 
225 canina) and willow species (Salix cinerea, Salix caprea).

226 Three managed forests nearby Vorsø representing typical

227 management scenarios and hence relevant for comparison to the

228 Vorsø passive rewilding case were pointed out:

229 - Tranbjerg (hereafter Tran_Y3), a 4.51 ha young managed stand

230 planted in 1983 on former farmland. The main tree species is oak

231 (Quercus robur). Drainage is unchanged. There has been no

232 fencing. Managers performed weeding after planting, and thinning

233 of the stand has been carried out a couple of times.

234 - Fløjstrup (hereafter Fløj_Y4), a 0.92 ha young managed stand

235 established in 1983 by natural regeneration after a clear-cut.

236 The main tree species is sycamore maple (Acer pseudoplatanus)

237 mixed with beech (Fagus sylvatica) and ash trees (Fraxinus

238 excelsior). There is only surface drainage and the stand was too

239 wet for forest machinery to operate. The stand was fenced during

240 regeneration and thinning has been carried out 3-4 times to

241 control numbers of trees and remove some tree species.

242 - Stensballe (hereafter Sten_M/O), a 20.42 ha semi-old stand of

243 mainly broadleaved trees under commercial forest management. The

244 main species is beech (Fagus sylvatica). Mature trees are

245 selectively harvested and the upbringing of new trees is secured

246 by natural regeneration, leading to a mixed stand of age

247 classes. 


\section{Lidar-derived metrics}

249 Lidar-data was acquired with an airborne Optech Altm Gemini 250 Laser Altimeter system in March 2007 ("kortforsyningen.dk," 251 2015) with a footprint of $40 \mathrm{~cm}$. The point cloud density was one 252 return per $2.2 \mathrm{~m}^{2}$ on bare ground and included up to two returns 253 per pulse with a vertical and horizontal accuracy of 0.67 and $2540.06 \mathrm{~m}$, respectively. We derived 25 metrics from the height255 normalized point cloud after deleting overlapping returns. The 25625 metrics were found in existing lidar literature and selected 257 on a criteria of being used in comparison to manual ground 258 surveys in previous studies of for being alike such metrics

259 (Table. S1). We performed calculations and processing in the 260 ArcGIS (Esri ArcMap, version 10.2.2.3552) software and LastooLS 261 (Rapidlasso, 2015, version 141117). Basic grid cells measured 10 $262 \times 10$ meters ensuring sufficient returns per cell for statistical 263 treatment.

We furthermore computed 25 metrics of horizontal

265 heterogeneity based on the first 25 metrics, by calculating the 266 standard deviation of the values for each cell (10 ×10 meters) 267 and the eight surrounding cells and ascribing this SD-value to 268 each cell. Thereafter the cells were aggregated into bigger 269 cells of 30 x 30 meters, by taking the mean of the SD-values of 270 nine adjacent cells to reduce pseudo-replication by adjacent 271 cells influencing each other in the SD calculation. 


\section{Statistical analysis}

273 We extracted the values from each $10 \times 10$ meters cell of the 25 274 metrics for vertical structure and each 30 x 30 meters cell of 275 the 25 metrics for horizontal heterogeneity and exported it to 276 the $R$ ( $\mathrm{R}$ i386 3.1.2Ink, the R core Team 2014) statistical 277 software. We scaled and centered the values and completed one 278 Principal Component Analysis (PCA) (hereafter PCA_10m) based on 279 values from the 10 x 10-meter grid cells ( $=7319$ ), and another 280 one (hereafter PCA_30m) based on the 30 x 30-meter grid cells $281(n=1002)$.

Based on a threshold of about 90\% explained variance, 283 the first five principal axes were tested for significant 284 differences in medians and variances among the three managed 285 forests and seven rewilded zones of Vors $\varnothing$ focusing on the even286 aged stands (Table 1), using Kruskal-Wallis as a non-parametric 287 test for medians and Levene's test for variance. In addition, we 288 included extreme PCA axes values as a measure of unique 289 vegetation structure in the analyses.

290 Table 1 Groupings for age-specific pairwise comparisons of 291 rewilded forest zones on Vorsø and nearby managed forests

292 The two zones, V_Y1 and V_Y2, have similar histories and Tran_Y3 293 and Fløj_y4 are approximately of the same age. V_M1 and V_M2 294 have similar histories. V_01, V_02 and V_03 were rewilded 
295 simultaneously, but their initial conditions differed, e.g. in 296 terms of species composition. The managed Sten_M/O forest is 297 included in two age groups, because the age of the oldest trees 298 corresponds roughly to the age of the mid-aged group, but at the 299 same time, the managed forest is persistently kept at this stage 300 due to tree harvest. Sten_M/O therefore also serves as an 301 example of the managed alternative to the rewilded forests in 302 this study

303

304 Results

305 Within the young stands, the Vorsø zones have the highest 306 variances on four of five axes of PCA_10m compared to the young 307 managed forests (Fig. 3 and 4, Table 2).

308 Fig. 3 Boxplots of PCA values for PCA 10m and PCA 30m. A-E:

309 Boxplots of the values of axes 1, 2, 3, 4 and 5 of the PCA_10m 310 and F-J: Boxplots of the values of axes 1, 2, 3, 4 and 5 of the 311 PCA 30m. Number of 10-meter cells in each area in parentheses 312 and number of 30-meter cells in brackets. V_ol of Vors $\varnothing$ (n=618) $313[n=73], V \_02$ of Vors $\varnothing$ (n=263) [n=31], V_o3 of Vors $\varnothing \quad(n=36)$ $314[n=4]$, Sten_M/O $(n=2041)[n=275], V \_M 2$ of Vorsø $(n=912)$ [n=120], 315 V_M1 of Vorsø (n=1496) [n=199], V_Y1 of Vorsø (n=511) [n=74], 316 V_Y2 of Vorsø (n=899) [n=127], I, Tran_y3 (n=450) [n=79] and J, 317 Fløj_y4 (n=93) [n=20]. There is a rough gradient of age, placing 
318 the oldest stands to the left and the youngest to the right. The 319 whiskers mark the minimum and maximum values omitting outliers. 3205 and 95 percentiles are marked with dots. Note that the 321 relative variance alternates between the stands and axes, 322 meaning that the gradients (axes) are varying, suited for 323 differentiating specific types of structure

324 Fig. 4 Maps of PCA values. A: Values of PCA_10m axis 1, which 325 primarily is a gradient of vegetation height. The highest values 326 are found among the oldest vegetation of V_OI and Sten_M/O, 327 along with the younger stand V_M2, which where rapidly colonized 328 by sycamore maple. Red-colored cells indicate widespread open 329 areas in three of the Vorsø zones. B: Values of PCA_10m axis 5, 330 which is a gradient from bare ground to low and sparse 331 vegetation, subscribing intermediate values to all kinds of 332 taller vegetation. Low values (red) specify the bare ground. 333 Axis 5 is one axis that differentiates the two youngest zones 334 (V_Y1 and V_Y2) on both median and variance, though it is 335 visible that the two former fields contain the same vegetation 336 structural components according to the mapping of axis values. 337 For both $A$ and B: Vorsø zones corresponds to Fig. 1 
346 Table 2 Pairwise comparisons of stands within groupings 347 according to age

348 Pairwise tests of medians and variances of the first five axes 349 of the PCA_10m (left part of tables) and PCA_30m (right part of 350 tables). Kruskal-Wallis and Levene's test was used to test for 351 differences of medians and variances, respectively. Asterisks 352 (*) indicate significance for medians, and plusses (+) indicate 353 significance for variance. Non-significance of both medians and 354 variance is indicated with non-sign. Significance levels have 355 been Bonferroni-corrected by dividing 0.05 with 225. The 356 corrected level of significance used here was 0.000222 * */+ = 357 below $0.000222, * * /++=$ below $0.00001, * * * /+++=$ below 0.000001 . 358 The columns of variance $\left(\sigma^{2}\right)$ list variance values, and the 359 largest variance values for the axes within each grouping are in 360 bold and italics. The rows marked dissim. list, how many of the 36110 pairwise tests that are significantly different as a measure 362 of dissimilarity between two areas. A: Pairwise tests between 363 younger stands (V_Y1, V_Y2, Tran_Y3 and Fløj_Y4). B: Pairwise 364 tests between mid-aged stands (V_M1, V_M2 and Sten_M/O). C: 365 Pairwise tests between older stands (V_O1, V_O2, V_O3 and 366 Sten_M/O). A complete table of all pairwise comparisons without 
367 regarding groupings are present in table s2 and S3 for PCA_10m 368 and PCA_30m, respectively.

369 The PCA_30m supports those findings, showing significantly

370 larger variance on four of the five axes and a significantly

371 smaller median on axis 1 compared to both managed stands (Table 372 2) .

373 The analysis points out the similarity between the two 374 youngest rewilded zones of Vorsø, despite significantly 375 different variances and medians of axes 2 and 5 (PCA_10m), 376 visual analyzing of the map output clarifies overall similarity 377 of the two youngest Vorsø zones (Fig 4, Fig. S1 and S2). The 378 PCA_30m confirms this, as no significant differences are found 379 between V_Y1 and V_Y2 (Table 2). Furthermore, low values in 380 PCA_10m axis 2 show, in compliance with reality, that gaps are 381 present in $V_{-} Y 1$ and $V_{-} Y 2$ (and V_M1) while not in Tran_Y3 and 382 Fløj_Y4.

In contrast to the similar development of the two 384 youngest rewilded farmlands, the two mid-aged zones of Vors $\varnothing$, 385 V_M1 and V_M2, are significantly different in nine of ten 386 pairwise comparisons of PCA_10m axes values, which correspond to 387 the number of significant differences to the managed Sten_M/O 388 forest. The southern and eastern parts of V_M2 mimics the 389 Sten_M/O, which is not the case for the V_M1 (visible at Fig 4 390 and Fig. S2). According to the tests of the PCA_30m, the two 
391 mid-aged rewilded zones are found less different with a 392 dissimilarity value of 4, compared to 7 and 10 when compared to 393 Sten_M/O (Table 2). Furthermore, extremely low values of PCA_30m 394 axis 3 clarify that V_M1 keeps evolving new types of 395 heterogeneity compared to the 50-year younger vegetation of V_Y1 396 and V_Y2. An example of what the two latter cannot produce, is 397 the mix of older trees, scrub, gaps and dead wood (Fig. 2F, Fig. 398 S2). In addition, after 78 years of spontaneous regeneration, 399 the V_M1 still holds gaps surrounded by shrubs, which is 400 detected by PCA_10m axes 2 and 5 (low values) and PCA_30m axis 2 401 (high values) (Fig 3B,D, G, see Table S4 for axes 402 interpretation).

403 Comparisons within the oldest group of stands show that 404 they all differ according to vegetation structure, and that V_O3 405 presumably contains too few cells for statistical analyses, 406 especially in PCA_30m, where no significant differences are 407 found at all. Sten_M/O and V_O1 have the highest dissimilarity 408 values on both PCA_10m and PCA_30m; the latter one pointing at 409 V_O1 as the most heterogeneous by having significantly larger 410 variances on axes 1 and 5, besides extreme low values and a 411 smaller median on axis 1, meaning more heterogeneous vegetation 412 according to height (Fig 3, Fig. S2). The PCA axes were interpretable to some extent by 414 analyzing the loadings of metrics to the eigenvectors in 
415 combination with ground inspections, although; especially the 416 PCA_30m results were complex due to the underlying calculations 417 (Table S4, S5 and S6). The PCA_30m seemed to be especially 418 suitable to detect edge vegetation along glades and in addition, 419 extreme cell values of the PCA_30m axes were useful to identify 420 unique vegetation structural attributes, e.g. in the V_M1 and 421 V_O1 (Fig. S2).

\section{Discussion}

\section{Rewilding of abandoned farmland}

424 The youngest zones on Vorsø and the youngest managed forests 425 (Tran_Y3 and Fløj_Y4) have developed completely differently, 426 which we conclude must be due to the different afforestation 427 techniques used, as well as the related management (fencing and 428 weeding in Tran_Y3 and Fløj_Y4). The two latter are evolving 429 homogeneously in line with previous investigations of 430 intensively managed forests (Fuller, Foster, \& McLachlan, 1998; 431 Nilsson et al., 2001). The larger median values for the managed 432 stands on PCA_10m axis 1 clearly indicate that the dense 433 establishment led to a higher growth rate, even compared to 434 V_M1, which has had 50 more years to grow tall vegetation. A 435 recent study modelling post-disturbance spontaneous regeneration 436 in the Bavarian Forest National Park, Germany, showed uniform 437 development of mean tree height across five sites over 80 years, 438 despite differences in their starting points (Hill, Latifi, 
439 Heurich, \& Müller, 2017). In contrast, the stand heights

440 investigated in this paper develop differently. Since soil and

441 climatic conditions are similar within the study area, we assign

442 those structural differences to the method of establishment.

443 The relatively similar vegetation development in the

444 two young Vorsø zones (V_Y1 and V_Y2) indicates predictability

445 of underlying controlling ecological factors, also found in

446 other studies (Bullock et al., 2002; Prach \& Pyšek, 2001),

447 despite the complex interactions between the factors influencing

448 development. The similar development suggests that spontaneous

449 regeneration might be predictable, when conditions are well

450 known as assumed by ongoing vegetation development modelling

451 e.g. (Hill et al., 2017).

452 The two fields abandoned in 1929 (V M1 and V M2) also

453 predominantly shared the same conditions. However, they

454 developed quite distinct vegetation structure, identified by

455 significantly different median and variance values in nine of

456 ten cases (PCA_10m) (Table 2). Different seed input is concluded

457 as being the main reason for this divergence (Halberg \&

458 Gregersen, 2010). The prevailing western wind provided an

459 effective vector for seeds of the fast-growing Acer

460 pseudoplatanus trees from V_O2 and V_O3 to V_M2, causing the

461 divergence between V_M2 and V_M2, which underlines the broadly

462 acknowledged importance of seed banks and seed supplies (Benayas 
463 et al., 2008; De Steven, 1991; Olsson, 1987). The ongoing 464 diverging development of vegetation through 78 years in the two 465 abandoned field sites was hence largely predictable when general 466 successional ecology was considered and are in line with a 467 recent study concluding that old-growth spatial pattern is 468 determined by the initial patterns of regeneration (Hill et al., 469 2017). Thus, the combination of the recorded site history and 470 the statistical result presented in the two above pairwise 471 comparisons, despite different outcomes, underpin that designing 472 spontaneous regeneration projects with specific aims for the 473 vegetation structural outcome is possible when considering 474 ecological theory and site-specific conditions carefully. For 475 instance, a heavy seed supply into an abandoned farmland site 476 might lead to structural development similar to managed stands 477 (Sten_M/O in this case), at least for the first 78 years. We 478 believe that site managers should make use of these basic rules 479 in forest ecology when designing conservation projects. In general, passive regeneration on Vors $\varnothing$ is 481 progressing at a slow pace compared to other studies (V. A. 482 Cramer et al., 2008; Verburg \& Overmars, 2009). After 28 and 78 483 years, respectively, three spontaneous regenerated zones of 484 Vorsø still hold shrub-dominated low vegetation and open areas. 485 The timespan of 20 - 60 years for the development of stands of 486 mid-successional tree species on abandoned farm land, concluded 
487 in previous studies (V. A. Cramer et al., 2008; Verburg \& 488 Overmars, 2009), fail to comply with most spontaneous

489 regenerated areas on Vorsø, which are too dominated by gaps and 490 low and sparse vegetation to fulfill this criteria. Successional 491 arresting factors such as (high water level, drought and 492 competition from herbs and grasses) are all present on Vorsø; 493 however, as former farmland it should be categorized as having 494 moderate conditions for colonization of woody vegetation, e.g 495 compared to abandoned mining sites (Macdonald et al., 2015) or 496 other areas exposed to heavy disturbances. In this light, we 497 suggest a prolongation of the recognized timespan of natural 498 afforestation under moderate conditions, such that the theory 499 can comply with moderate conditions with a low degree of seed 500 input from trees.

501 For biodiversity, the slow development might be 502 beneficial, especially if early successional stages are 503 underrepresented in a landscape level (Angelstam, 1998; Brawn, 504 Robinson, \& Thompson III, 2001). This is also supported by a 505 study reviewing early-successional forest ecosystems, arguing 506 that the prevailing focus on recovery of the closed-canopy stage 507 should be shifted to greater focus on the qualities of the 508 early-successional stages (Swanson et al., 2011). Besides, 509 naturally developed gaps are found more valuable to biodiversity 510 than artificial gaps created by thinning operations (Seidel, 
511 Ehbrecht, \& Puettmann, 2016). Thus, the spontaneous regeneration

512 on Vorsø is generally in line with desired vegetation

513 development according to international research, and of

514 presumable interest to other afforestation projects in abandoned

515 farmland sites in the temperate zone.

\section{Rewilding of existing forests}

517 This study evaluates rewilding of existing forests by comparing

518 sites of unmanaged forest stands, which has previously been

519 managed, to one stand (Sten_M/O) still under silvicultural

520 management in terms of tree harvest, drainage and pest control.

521 The results indicate a relatively high degree of vegetation

522 structure heterogeneity in the V_O1 rewilded Vors $\varnothing$ forest. The

523 stand is dominated by mature oak and ash trees, and shows the

524 lowest median value on the axis 3 of PCA_10m (Fig 3C), meaning

525 that it has the most open canopy layer among the older stands,

526 following disturbances by cormorant colonies, windfall and Dutch

527 elm disease (Halberg \& Gregersen, 2010). The reason for greater

528 windfall impact here, e.g. compared to the nearby managed

529 Sten_M/O forest, is the increased water level, caused by

530 drainage destruction, which prevents the roots from growing deep

531 into the ground and causing existing roots to rot (Halberg and

532 Gregersen, 2010). When we combine our results to the site

533 history, our findings are in line with a Canadian study

534 reporting that stands which have undergone canopy disturbance 
535 can evolve a high degree of spatial pattering (Zenner, 2005).

536 According to international research, the impact of disturbances

537 to biodiversity through unique forest structure is well

538 documented (Berg et al., 1994; Navarro \& Pereira, 2012; Nilsson

539 et al., 2001). We argue that the slow, moderate and persistent

540 dynamics that have occurred in this rewilded stand (V_O1) have

541 produced such vegetative attributes crucial to biodiversity

542 (Fig. S2), and interpret it as being in line with the mediate

543 disturbance hypothesis.

544 In contrast, V_O2 was subject to heavy and devastating

545 disturbance from a packed colony of great cormorants in the

546 1980s, which entirely terminated the vegetation of tall-stemmed

547 trees (Halberg \& Gregersen, 2010). Instead of creating a unique

548 structural composition, it rather pushed back the succession to

549 the shrub or early stand stage (Fig 2E). Our analyses cannot

550 detect increased heterogeneity in this rewilded forest compared

551 to a managed forest, and are therefore contrary to the findings

552 in a review of post-disturbance vegetation structure, which

553 state that regenerated vegetation is more heterogeneous than

554 typical closed-canopy forest (Swanson et al., 2011). The

555 divergence to our findings could be due to more homogenous stand

556 replacement following the heavy impact of cormorant colonies

557 compared to the regenerated vegetation following e.g. wildfires

558 or windstorms. 


\section{Evaluation of the presented method}

560 The capability of distinguishing forest areas by this method

561 seems to be very sensitive, as it finds the overall similar

562 vegetation development of the two young spontaneously

563 regenerated zones (V_Y1 and V_Y2) to be different on 6 out of 10

564 parameters. The test of PCA_30m axes does not find any

565 significant differences between these two former fields.

566 Previous research shows that a scale of minimum $500 \mathrm{~m}^{2}$ is

567 necessary to adequately detect defining structural attributes of 568 different forest categories (Zenner, 2005). This is in line with 569 our findings, where the $900-\mathrm{m}^{2}$ grid cells confirm the similarity 570 of the young Vorsø stands better than the 100-m² grid cells, 571 although the methods are different.

573 PCA_30m) and Fløj_Y4 (0.92 ha; 20 cells in PCA_30m) reveal that 574 we reached the lower threshold of cell numbers. The 36 cells of 575 V_O3 in PCA_10m apparently satisfy the statistical analysis to 576 achieve trustworthy results. Increased point density of point 577 clouds allows researchers to reduce cell size to $1-\mathrm{m}^{2}$ or even 578 less (Müller \& Brandl, 2009), providing 100 cells per $100 \mathrm{~m}^{2}$ 579 instead of only one, as in this paper, though still in 580 consideration of the above discussed scale issue. However, the 581 high degree of significant results in the pairwise tests in 582 combination with corresponding point densities in the 
583 literature, convince us of the sufficient point density in this 584 study (in general between 0.5 and 0.9 per $\mathrm{m}^{2}$ ). A study from 585 Colorado, USA, (Hall, Burke, \& Box, 2005) calculated useful 586 estimates of stand height, total above-ground biomass, foliage 587 biomass and basal area from an average point density of 1.23 588 returns per $\mathrm{m}^{2}$. A study from the UK (Boyd \& Hill, 2007) analyzed 589 lidar intensity values captured over an area of woodland based 590 on an average point cloud density of one return per $4.83 \mathrm{~m}^{2}$, and 591 an Italian study (Mura, McRoberts, Chirici, \& Marchetti, 2015) 592 estimated indices of structural diversity by using an average 593 density of 1.5 pulses per $\mathrm{m}^{2}$. The PCA assessment ensures that the information in the 595 point cloud retrieved by the calculated metrics is analyzed by 596 non-correlated principal components, hereby avoiding that the 597 metrics contribute with correlated information. Assumable, 598 single lidar-derived metrics could explain the main part of the 599 information instead of PCA axes. However, the wide number of 600 metrics contributing to the eigenvectors in this study (Table S5 601 and S6) also clarifies that the PCA axes express a complex 602 interaction of metrics, which could be particular useful when 603 dealing with low-density point clouds. A previous investigation 604 succeeded in using PCA for choosing the three most significant 605 metrics among nine metrics for modelling above-ground biomass 606 across three forest study sites (Li, Andersen, \& McGaughey, 
607 2008). We reason that the PCA axes are better suited for

608 pairwise comparisons of forest sites than specific metrics, and

609 that it is a different task to model concrete forest

610 measurements, i.e. above-ground biomass, compared to designating

611 key structural attributes suitable for differentiation of

612 vegetation structure between stands. This is supported by the

613 fact that two stands holding similar biomass can have very

614 different structural composition. More research is needed to

615 explore which methods are best suited for evaluating vegetation

616 structural quality of forest sites using wall-to-wall lidar

617 data.

618

As a disadvantage of the suggested simple method, we

619 should mention the difficulties of ecological meaningful axes

620 interpretation in some cases. In addition, it is a drawback that

621 the PCA axes values cannot be directly compared to equivalent

622 studies of other sites. The creation of a multi-site likewise

623 analysis could form the foundation of a common reference dataset

624 of PCA axes values, at least for delimited homogenous areas e.g. 625 the northern temperate broadleaved tree species dominated zone.

626 However, this is beyond the scope of this study.

\section{Conclusion}

628 The presented lidar-based evaluation of vegetation structure 629 resulting from different afforestation strategies and management 
630 actions, successfully performs statistical tests of pairwise 631 structural similarities and differences between forest stands; 632 it points out key structural attributes and, at least to some 633 extent, provides interpretable axes. The study takes advantage 634 of already provided ground and site historical data, which turns 635 out to constitute a well-functioning combination with the lidar 636 analysis that can presumably be applied on large number of sites 637 world wide.

We find that spontaneous processes for establishment of 639 forests in general leads to increased structural heterogeneity 640 compared to forests under silvicultural management, as well as 641 rewilding of existing forests leads to increased disturbance 642 dynamics, which can result in increased vegetation heterogeneity 643 or terminate and homogenize the vegetation. Despite the large number of factors influencing 645 spontaneous afforestation, this study indicates that underlying 646 ecological factors controlling vegetation development might be 647 predictable to a large degree. We therefore agree on the need to 648 put more effort into evaluation of existing and future 649 spontaneous regeneration projects in order to exploit and learn 650 from these ecological field based laboratories (Cramer et al., 651 2008; Hobbs \& Cramer, 2007b), hereby supporting managers in 652 improving general conditions for biodiversity in areas under 653 afforestation. 
654

655

656

658

659

660

661

662

670

671

672

673

674

675

676

677

678

679

680

681

682

683

684

685

686

687

688

\section{Acknowledgements}

Thanks to Brody Steven Sandel for kindly helping with the Rstatistical software and to Jens Gregersen for a thorough guidance on Vors $\varnothing$. The municipality of Aarhus has kindly provided information about the Tranbjerg and Fløjstrup Forests. Thanks to Ari Arnold for linguistic review. Contains material from the Danish Department of Data Supply and Efficiency "Styrelsen for Dataforsyning og Effektivisering", DHM2007 / Punktsky .

\section{References}

Angelstam, P. K. (1998). Maintaining and restoring biodiversity in European boreal forests by developing natural disturbance regimes. In Journal of Vegetation Science (Vol. 9, pp. 593602). Retrieved from http: / / www. scopus. com/inward/record.url?eid=2-s2.0$0031741215 \&$ partnerID=tZOtx3y1

Benayas, J. M. R., Bullock, J. M., \& Newton, A. C. (2008). Creating woodland islets to reconcile ecological restoration, conservation, and agricultural land use. Frontiers in Ecology and the Environment, 6(6), 329-336. Retrieved from http://apps.isiknowledge.com/full_record.do?product=Wos\&searc h_mode=General Search\&qid=1\&SID=T2oZyVyMNOTHw f $3 \mathrm{ThOX} \&$ page=1 \&doc $=\overline{1}$

Berg, A., Ehnstrom, B., Gustafsson, L., Hallingback, T., Jonsell, M., \& Weslien, J. (1994). Threatened Plant, Animal, and Fungus Species in Swedish Forests: Distribution and Habitat Associations. Conservation Biology, 8(3), 718-731. https://doi.org/10.1046/j.1523-1739.1994.08030718.x

Boyd, D., \& Hill, R. (2007). Validation of airborne lidar intensity values from a forested landscape using HYMAP data: preliminary analyses. IAPRS Volume 36, Part 3 / W52, (ISPRS Workshop on Laser Scanning 2007 and SilviLaser 2007, Espoo, September 12-14, 2007, Finland), 71-76. Retrieved from http: //www.isprs.org/proceedings/XXXVI/3W52/final_papers/Boyd_2007.pdf 
689

690

691

692

693

694

695

696

697

698

699

700

701

702

703

704

705

706

707

708

709

710

711

712

713

714

715

716

717

718

719

720

721

722

723

724

725

726

727

728

729

730

731

Brawn, J. D., Robinson, S. K., \& Thompson III, F. R. (2001). The Role of Disturbance in the Ecology and Conservation of Birds 1. Annual Review of Ecology and Systematics, 32(1), 251-276. https://doi.org/10.1146/annurev.ecolsys.32.081501.114031

Bullock, J., Moy, I., \& Pywell, R. (2002). Plant dispersal and colonization processes at local and landscape scales. In J. Bullock, R. Kenward, \& R. Hails (Eds.), Dispersal ecology (pp. 279-299). Retrieved from

https: / / www.google.com/books?hl=en\&lr=\&id=DY6mDiLw4RkC\&Oi=fnd

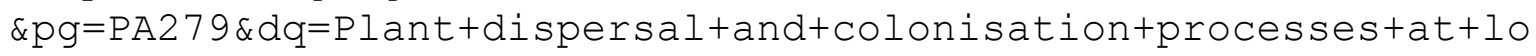
caltand+landscape+scales. \&ots=FhZuP-on-

$0 \&$ sig=w_tdtU8hbmcSCWbDg5A-4EJV0Cs

Bässler, C., Stadler, J., Müller, J., Förster, B., Göttlein, A., \& Brandl, R. (2010). LiDAR as a rapid tool to predict forest habitat types in Natura 2000 networks. Biodiversity and Conservation, 20(3), 465-481. https://doi.org/10.1007/s10531010-9959-x

Christensen, M., \& Emborg, J. (1996). Biodiversity in natural versus managed forest in Denmark. Forest Ecology and Management, 85(1-3), 47-51. https://doi.org/10.1016/S0378$1127(96) 03749-8$

Cramer, V. A., Hobbs, R. J., \& Standish, R. J. (2008). What's new about old fields? Land abandonment and ecosystem assembly. Trends in Ecology \& Evolution, 23(2), 104-112. Retrieved from http: / / apps.isiknowledge. com/full_record.do?product=WOS\&searc h_mode=General Search\&qid=3\&SID=T2oZyVyMNOTHwf3ThOX \&page $=1 \&$ doc $=\overline{1}$

De Steven, D. (1991). Experiments on mechanisms of tree establishment in old-field succession: seedling emergence. Ecology, $72(3), 1066-1075$.

Ehbrecht, M., Schall, P., Juchheim, J., Ammer, C., \& Seidel, D. (2016). Effective number of layers: A new measure for quantifying three-dimensional stand structure based on sampling with terrestrial LiDAR. Forest Ecology and Management, 380, 212-223. https://doi.org/10.1016/j.foreco.2016.09.003

Fuller, T., Foster, D., \& McLachlan, T. (1998). Impact of human activity on regional forest composition and dynamics in central New England. Ecosystems, 1(1), 76-95. Retrieved from http: / / apps.isiknowledge. com/full_record.do?product=WOS\&searc h_mode=General Search \&qid=2\&SID=X2 $\bar{f}$ wHj qPfVgEUE $5 \mathrm{JcMk} \&$ page $=1 \&$ doc $=\overline{1}$ 
732

733

734

735

736

737

738

739

740

741

742

743

744

745

746

747

748

749

750

751

752

753

754

755

756

757

758

759

760

761

762

763

764

765

766

767

768

769

770

771

772

773

774

775

Götmark, F. (2013). Habitat management alternatives for conservation forests in the temperate zone: Review, synthesis, and implications. Forest Ecology and Management, 306, 292-307. Retrieved from

http: / / apps.isiknowledge. com/full_record.do?product=UA\&search mode=GeneralSearch\&qid=1\&SID=X2 I seLGhitAz3dgxlgt\&page=1\&doc= $\overline{1}$

Halberg, K., \& Gregersen, J. (2010). Vorsø - et fristed for naturen (in Danish) (First edit). Eigil Holms Forlag.

Hall, S., Burke, I., \& Box, D. (2005). Estimating stand structure using discrete-return lidar: an example from low density, fire prone ponderosa pine forests. Forest Ecology and Management, 208(1-3), 189-209. Retrieved from http://apps.isiknowledge.com/full_record.do?product=Wos\&searc h_mode=General Search\&qid=1\&SID=Z1 ÜBIO9UxbUGAcVVj Jp\&page=1\&doc $=\overline{1}$

Hill, S., Latifi, H., Heurich, M., \& Müller, J. (2017). Individual-tree- and stand-based development following natural disturbance in a heterogeneously structured forest: A LiDAR-based approach. Ecological Informatics, 38. https://doi.org/10.1016/j.ecoinf.2016.12.004

Hobbs, R., \& Cramer, V. (2007a). Old field dynamics: regional and local differences, and lessons for ecology and restoration. In V. Cramer \& R. Hobbs (Eds.), Old fields: dynamic and restoration of abandoned farmland. (pp. 309-317). Washington: Island Press. Retrieved from https://www.google.com/books?hl=en\&lr=\&id=SB3zQAK_GGIC\&Oi=fnd $\& \mathrm{pg}=\mathrm{PA} 309 \& \mathrm{dq}=0 \mathrm{ld}+\mathrm{field}+\mathrm{dynamics}$ :+regional+and+local+differenc es, tand+lessons+fortecology+and+restoration. \&ots=0i Ly 8 cSF9P\&s ig=Tkaax_IO9ceT4dT18gPtvCH3xZU

Hobbs, R., \& Cramer, V. (2007b). Why old fields? Socioeconomic and ecological causes and consequences of land abandonment. In V. Cramer \& R. Hobbs (Eds.), Old fields: dynamic and restoration of abandoned farmland. (pp. 1-14). Washington: Island Press.

Hofmeister, J., Hosek, J., \& Brabec, M. (2015). Value of old forest attributes related to cryptogam species richness in temperate forests: A quantitative assessment. Ecological Indicators, 57, 497-504. https://doi.org/10.1016/j.ecolind.2015.05.015

Ishii, H., Tanabe, S., \& Hiura, T. (2004). Exploring the relationships among canopy structure, stand productivity, and biodiversity of temperature forest ecosystems. Forest Science, 50(3), 342-355. Retrieved from 
776

777

778

779

780

781

782

783

784

785

786

787

788

789

790

791

792

793

794

795

796

797

798

799

800

801

802

803

804

805

806

807

808

809

810

811

812

813

814

815

816

817

818

http: / / apps.isiknowledge.com/full_record.do?product=UA\&search

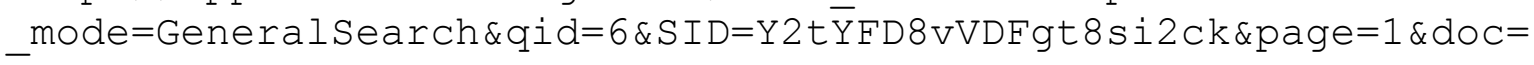
$\overline{1}$

kortforsyningen.dk. (2015). Retrieved October 1,2015, from http: //download.kortforsyningen.dk/

Li, Y., Andersen, H.-E., \& McGaughey, R. (2008). A Comparison of Statistical Methods for Estimating Forest Biomass from Light Detection and Ranging Data. Western Journal of Applied Forestry, 23(4), 223-231. Retrieved from http: / / apps.isiknowledge. com/full_record. do?product=WOS\&searc h_mode=General Search\&qid=1\&SID=U1RtIYY2t5SrWX3X2B3\&page=1 \&doc $=\overline{3}$

Listopad, C. M. C. S., Köbel, M., Príncipe, A., Gonçalves, P., \& Branquinho, C. (2018). The effect of grazing exclusion over time on structure, biodiversity, and regeneration of high nature value farmland ecosystems in Europe. Science of the Total Environment, 610-611, 926-936. https://doi.org/10.1016/j.scitotenv.2017.08.018

Macdonald, S. E., Landhäusser, S. M., Skousen, J., Franklin, J., Frouz, J., Hall, S., ... Quideau, S. (2015). Forest restoration following surface mining disturbance: challenges and solutions. New Forests, 46(5-6), 703-732. https://doi.org/10.1007/s11056-015-9506-4

Mura, M., McRoberts, R. E., Chirici, G., \& Marchetti, M. (2015). Estimating and mapping forest structural diversity using airborne laser scanning data. Remote Sensing of Environment, $170,133-142$.

Müller, J., \& Brandl, R. (2009). Assessing biodiversity by remote sensing in mountainous terrain: the potential of LiDAR to predict forest beetle assemblages. Journal of Applied Ecology, 46(4), 897-905. https://doi.org/10.1111/j.1365$2664.2009 .01677 . \mathrm{x}$

Navarro, L. M., \& Pereira, H. M. (2012). Rewilding Abandoned Landscapes in Europe. Ecosystems, 15(6), 900-912. https://doi.org/10.1007/s10021-012-9558-7

Nielsen, A. B., \& Jensen, R. B. (2007). Some visual aspects of planting design and silviculture across contemporary forest management paradigms - Perspectives for urban afforestation. Urban Forestry \& Urban Greening, 6(3), 143-158. https://doi.org/10.1016/j.ufug.2006.12.002

Nilsson, S. G., Hedin, J., \& Niklasson, M. (2001). Biodiversity and its assessment in boreal and nemoral forests. Scandinavian Journal of Forest Research, 16(1), 10-26. 
819

820

821

822

823

824

825

826

827

828

829

830

831

832

833

834

835

836

837

838

839

840

841

842

843

844

845

846

847

848

849

850

851

852

853

854

855

856

857

858

859

860

Retrieved from http://www.scopus.com/inward/record.url?eid=2s2.0-0000823877\&partnerID=tzotx3y1

Olsson, E. G. (1987). Effects of dispersal mechanisms on the initial pattern of old-field forest succession. Acta Oecologica/Oecologia Generalis, 8(3), 379-390.

Prach, K., \& Pyšek, P. (1994). Spontaneous establishment of woody plants in central European derelict sites and their potential for reclamation. Restoration Ecology, 2(3), 190197. https://doi.org/10.1111/j.1526-100x.1994.tb00066.x

Prach, K., \& Pyšek, P. (2001). Using spontaneous succession for restoration of human-disturbed habitats: Experience from Central Europe. Ecological Engineering, 17(1), 55-62. https://doi.org/10.1016/s0925-8574(00)00132-4

Richnau, G., Wistrom, B., \& Nielsen, A. B. (2012). Creation of multi-layered canopy structures in young oak-dominated urban woodlands - The "ecological approach" revisited. Urban Forestry \& Urban Greening, 11(2), 147-158. https://doi.org/10.1016/j.ufug.2011.12.005

Roberts, M. R., \& Gilliam, F. S. (1995). Patterns and mechanisms of plant diversity in forested ecosystems: Implications for forest management. Ecological Applications, 5(4), 969-977.

Schnitzler, A. (2014). Towards a new European wilderness: Embracing unmanaged forest growth and the decolonisation of nature. Landscape and Urban Planning, 126, 74-80. https://doi.org/10.1016/j.landurbplan.2014.02.011

Sebek, P., Bace, R., Bartos, M., Benes, J., Chlumska, Z., Dolezal, J., ... Cizek, L. (2015). Does a minimal intervention approach threaten the biodiversity of protected areas? A multi-taxa short-term response to intervention in temperate oak-dominated forests. Forest Ecology and Management, 358, 80-89. https://doi.org/10.1016/J.FORECO.2015.09.008

Seidel, D., Ehbrecht, M., \& Puettmann, K. (2016). Assessing different components of three-dimensional forest structure with single-scan terrestrial laser scanning: A case study. Forest Ecology and Management, 381. https://doi.org/10.1016/j.foreco.2016.09.036

Simonson, W. D., Allen, H. D., \& Coomes, D. A. (2014). Applications of airborne lidar for the assessment of animal species diversity. Methods in Ecology and Evolution, 5(8), 719-729. https://doi.org/10.1111/2041-210X.12219

Stein, A., Gerstner, K., \& Kreft, H. (2014). Environmental heterogeneity as a universal driver of species richness 
861

862

863

864

865

866

867

868

869

870

871

872

873

874

875

876

877

878

879

880

881

882

883

884

885

886

887

888

889

890

891

892

893

894

895

896

897

898

899

900

901

902

903

across taxa, biomes and spatial scales. Ecology Letters, $17(7), 866-80$. https://doi.org/10.1111/ele.12277

Svenning, J.-C., Pedersen, P. B. M., Donlan, C. J., Ejrnæs, R., Faurby, S., Galetti, M., ... Vera, F. W. M. (2015). Science for a wilder Anthropocene: Synthesis and future directions for trophic rewilding research. Proceedings of the National Academy of Sciences of the United States of America, 113(4), 898-906. https://doi.org/10.1073/pnas.1502556112

Swanson, M. E., Franklin, J. F., Beschta, R. L., Crisafulli, C. M., Dellasala, D. A., Hutto, R. L., ... Swanson, F. J. (2011). The forgotten stage of forest succession: early-successional ecosystems on forest sites. Frontiers in Ecology and the Environment, 9(2), 117-125. https://doi.org/10.1890/090157

Syrjänen, K., Kalliola, R., Puolasmaa, A., \& Mattsson, J. (1994). Landscape structure and forest dynamics in subcontinental Russian European taiga. Annales Zoologici Fennici, $31(1), 19-34$.

Tews, J., Brose, U., Grimm, V., Tielbörger, K., Wichmann, M. C., Schwager, M., \& Jeltsch, F. (2004). Animal species diversity driven by habitat heterogeneity/diversity: The importance of keystone structures. Journal of Biogeography, 31(1), 79-92.

Thers, H., Brunbjerg, A. K., Læssøe, T., Ejrnæs, R., Bøcher, P. K., \& Svenning, J.-C. (2017). Lidar-derived variables as a proxy for fungal species richness and composition in temperate Northern Europe. Remote Sensing of Environment. https://doi.org/10.1016/j.rse.2017.08.011

Valbuena, R., Eerikäinen, K., Packalen, P., \& Maltamo, M. (2016). Gini coefficient predictions from airborne lidar remote sensing display the effect of management intensity on forest structure. Ecological Indicators, 60, 574-585. https://doi.org/10.1016/j.ecolind.2015.08.001

Verburg, P. H., \& Overmars, K. P. (2009). Combining top-down and bottom-up dynamics in land use modeling: exploring the future of abandoned farmlands in Europe with the Dyna-CLUE model.

Landscape Ecology, 24(9). https://doi.org/10.1007/s10980-0099355-7

Verheyen, K., Vanhellemont, M., \& Auge, H. (2015). Contributions of a global network of tree diversity experiments to sustainable forest plantations. Ambio, 1-13. https://doi.org/10.1007/s13280-015-0685-1

Zellweger, F., Baltensweiler, A., Ginzler, C., Roth, T., Braunisch, V., Bugmann, H., \& Bollmann, K. (2016). Environmental predictors of species richness in forest 
904 landscapes: abiotic factors versus vegetation structure.

905 Journal of Biogeography, 43, 1080-1090.

906 https://doi.org/10.1111/jbi.12696

907 Zenner, E. K. (2005). Investigating scale-dependent stand

908

909 heterogeneity with structure-area-curves. Forest Ecology and Management, 209(1), 87-100.

910

https://doi.org/10.1016/j.foreco.2005.01.004

911

912 


\section{Table $\mathbf{1}$ (on next page)}

Groupings for age-specific pairwise comparisons of rewilded forest zones on Vorsø and nearby managed forests.

The two zones, $V_{-} Y 1$ and $V_{-} Y 2$, have similar histories and Tran_Y3 and Fløj_Y4 are approximately of the same age. $\mathrm{V}_{-} \mathrm{M} 1$ and $\mathrm{V}_{-} \mathrm{M} 2$ have similar histories. $\mathrm{V}_{-} \mathrm{O} 1, \mathrm{~V} \_\mathrm{O} 2$ and $\mathrm{V}_{-} \mathrm{O} 3$ were rewilded simultaneously, but their initial conditions differed, e.g. in terms of species composition. The managed Sten_M/O forest is included in two age groups, because the age of the oldest trees corresponds roughly to the age of the mid-aged group, but at the same time, the managed forest is persistently kept at this stage due to tree harvest. Sten_M/O therefore also serves as an example of the managed alternative to the rewilded forests in this study. 


\begin{tabular}{ll}
\hline Groupings & Zones of Vors $\varnothing$ and managed forests \\
\hline Young stands & $V_{-} Y 1 ; V_{-} Y 2 ;$ Tran_Y3; Fløj_Y4 \\
Mid-aged stands & $V_{-} M 1 ; V_{-} M 2 ;$ Sten_M/O \\
Old stands & $V_{-} O 1 ; V_{-} O 2 ;$ V_O3; Sten_M/O
\end{tabular}

1 


\section{Table 2 (on next page)}

Pairwise comparisons of stands within groupings according to age.

Pairwise tests of medians and variances of the first five axes of the PCA_10m (left part of tables) and PCA_30m (right part of tables). Kruskal-Wallis and Levene's test was used to test for differences of medians and variances, respectively. Asterisks $(*)$ indicate significance for medians, and plusses (+) indicate significance for variance. Non-significance of both medians and variance is indicated with non-sign. Significance levels have been Bonferroni-corrected by dividing 0.05 with 225 . The corrected level of significance used here was $0.000222 . * /+=$ below $0.000222, * * /++=$ below $0.00001, * * * /+++=$ below 0.000001 . The columns of variance $\left(\sigma^{2}\right)$ list variance values, and the largest variance values for the axes within each grouping are in bold and italics. The rows marked dissim. list, how many of the 10 pairwise tests that are significantly different as a measure of dissimilarity between two areas. A: Pairwise tests between younger stands (V_Y1, V_Y2, Tran_Y3 and Fløj_Y4). B: Pairwise tests between mid-aged stands (V_M1, V_M2 and Sten_M/O). C: Pairwise tests between older stands (V_O1, V_O2, V_O3 and Sten_M/O). A complete table of all pairwise comparisons without regarding groupings are present in table S2 and S3 for PCA_10m and PCA_30m, respectively. 
PCA_10m

PCA 30m

\begin{tabular}{|c|c|c|c|c|c|c|c|c|c|c|c|}
\hline & & $\begin{array}{c}\text { variance } \\
\left(\sigma^{2}\right)\end{array}$ & $V_{-} Y 1$ & V_Y2 & Tran_Y3 & Fløj_Y4 & $\begin{array}{c}\text { variance } \\
\left(\sigma^{2}\right)\end{array}$ & V_Y1 & $V_{-} Y 2$ & Tran_Y3 & Fløj_Y4 \\
\hline V_Y1 & diss & & $x$ & 6 & 10 & 7 & & $\mathrm{x}$ & 0 & 8 & 6 \\
\hline V_Y1 & PC1 & 5,91 & $x$ & $* * *$ & $* * * /+++$ & $* * * /+++$ & 7,55 & $\mathrm{x}$ & non-sign. & $* * * /+++$ & $*$ \\
\hline V_Y1 & PC2 & 4,32 & $x$ & $* * * /+$ & $* * * /+++$ & +++ & 3,15 & $\mathrm{x}$ & non-sign. & $* * * /+++$ & $* * * /+$ \\
\hline V_Y1 & PC3 & 0,90 & $x$ & non-sign. & $* * * /+++$ & $* * *$ & 1,56 & $x$ & non-sign. & $* * * /+++$ & $* * *$ \\
\hline$v_{-}^{-} Y 1$ & PC4 & 1,54 & $x$ & ++ & $* /+++$ & $* * * /+++$ & 2,38 & $x$ & non-sign. & $* * /+++$ & +++ \\
\hline $\mathrm{V}_{-}^{-} \mathrm{Y1}$ & PC5 & 2,33 & $x$ & $* /+++$ & $* * * /+++$ & +++ & 0,28 & $x$ & non-sign. & non-sign. & $*$ \\
\hline V_Y2 & diss & & 6 & $\mathrm{x}$ & 9 & 7 & & 0 & $\mathrm{x}$ & 7 & 5 \\
\hline$v_{-}^{-} Y_{2}$ & PC1 & 6,08 & $* * *$ & $x$ & $* * * /+++$ & $* * * /+++$ & 6,88 & non-sign. & $x$ & $* * * /+++$ & $* * * /+$ \\
\hline$v_{-} Y_{2}$ & PC2 & 3,31 & $* * * /+$ & $x$ & $* * * /+++$ & +++ & 2,88 & non-sign. & $x$ & $* * * /+++$ & $* * * /++$ \\
\hline$v_{-}^{-} Y_{2}$ & PC3 & 0,69 & non-sign. & $x$ & $* * * /+++$ & $* * *$ & 1,56 & non-sign. & $x$ & $* * * /+++$ & $* *$ \\
\hline$v_{-}^{-} Y 2$ & PC4 & 0,95 & ++ & $x$ & +++ & $* * * /+++$ & 2,49 & non-sign. & $x$ & +++ & non-sign. \\
\hline V_Y2 & PC5 & 1,30 & $* /+++$ & $\mathrm{x}$ & $* /+++$ & +++ & 0,20 & non-sign. & $x$ & non-sign. & non-sign. \\
\hline Tran_Y3 & diss & & 10 & 9 & $x$ & 8 & & 8 & 7 & $x$ & 3 \\
\hline Tran_Y3 & PC1 & 0,27 & $* * * /++++$ & $* * * /+++$ & $x$ & $* * * /+++$ & 1,00 & $* * * /+++$ & $* * * /+++$ & $x$ & $* * *$ \\
\hline Tran_Y3 & PC2 & 0,16 & $* * * /+++$ & $* * * /+++$ & $x$ & $* * *$ & 0,07 & $* * * /+++$ & $* * * /+++$ & $x$ & $* * *$ \\
\hline Tran_Y3 & PC3 & 0,24 & $* * * /+++$ & $* * * /+++$ & $x$ & +++ & 0,29 & $* * * /+++$ & $* * * /+++$ & $x$ & $*$ \\
\hline Tran_Y3 & PC4 & 0,05 & $* /+++$ & +++ & $x$ & $* * * /+++$ & 0,09 & $* * /+++$ & +++ & $x$ & non-sign. \\
\hline Tran_Y3 & PC5 & 0,04 & $* * * /+++$ & $* /+++$ & $x$ & $* * * /+++$ & 0,19 & non-sign. & non-sign. & $x$ & non-sign. \\
\hline Fløj_Y4 & diss & & 7 & 7 & 8 & $\mathrm{x}$ & & 6 & 5 & 3 & $x$ \\
\hline Fløj_Y4 & PC1 & 0,66 & $* * * /+++$ & $* * * /+++$ & $* * * /+++$ & $\mathrm{x}$ & 0,65 & $*$ & $* * * /+$ & $* * *$ & $\mathrm{x}$ \\
\hline Fløj_Y4 & PC2 & 0,22 & +++ & +++ & $* * *$ & $\mathrm{x}$ & 0,23 & $* * * /+$ & $* * * /++$ & $* * *$ & $\mathrm{x}$ \\
\hline Fløj_Y4 & PC3 & 0,92 & $* * *$ & $* * *$ & +++ & $x$ & 0,74 & $* * *$ & $* *$ & $*$ & $x$ \\
\hline Fløj_Y4 & PC4 & 0,17 & $* * * /+++$ & $* * * /+++$ & $* * * /+++$ & $x$ & 0,16 & +++ & non-sign. & non-sign. & $x$ \\
\hline Fløj_Y4 & PC5 & 0,16 & +++ & +++ & $* * * /+++$ & $x$ & 0,35 & $*$ & non-sign. & non-sign. & $x$ \\
\hline
\end{tabular}

B

B $\quad$ PCA_10m

\begin{tabular}{|c|c|c|c|c|c|c|c|c|c|}
\hline & & $\begin{array}{c}\text { variance } \\
\left(\sigma^{2}\right)\end{array}$ & V_M2 & V_M1 & Sten_M/O & $\begin{array}{c}\text { variance } \\
\left(\sigma^{2}\right)\end{array}$ & V_M2 & V_M1 & Sten_M/O \\
\hline V_M2 & diss & & $x$ & 9 & 9 & & $x$ & 4 & 7 \\
\hline V_M2 & PC1 & 7,48 & $x$ & $* * * /+$ & $* * * /+++$ & 8,65 & $x$ & non-sign. & $* * *$ \\
\hline V_M2 & PC2 & 0,85 & $x$ & $* * * /+++$ & $* * *$ & 3,93 & $x$ & $* * *$ & $* * * /+++$ \\
\hline V_M2 & PC3 & 1,46 & $x$ & $* * * /+++$ & $* * * /+++$ & 1,07 & $x$ & $* * * /++$ & $* * *$ \\
\hline V_M2 & PC4 & 0,55 & $x$ & $* * * /+++$ & $* * * /+++$ & 0,98 & $x$ & $* * *$ & $* * * /+$ \\
\hline V_M2 & PC5 & 0,30 & $x$ & +++ & $* * * /++++$ & 0,91 & $\mathrm{x}$ & non-sign. & $* * *$ \\
\hline V_M1 & diss & & 9 & $x$ & 10 & & 4 & $\mathrm{x}$ & 10 \\
\hline V_M1 & PC1 & 6,32 & $* * * /+$ & $x$ & $* * * /+++$ & 6,09 & non-sign. & $\mathrm{x}$ & $* * * /+$ \\
\hline V_M1 & PC2 & 3,12 & $* * * /+++$ & $x$ & $* * * /+++$ & 3,57 & $* * *$ & $x$ & $* * * /+++$ \\
\hline V_M1 & PC3 & 0,66 & $* * * /+++$ & $x$ & $* * * /+++$ & 2,58 & $* * * /++$ & $x$ & $* * * /+++$ \\
\hline V_M1 & PC4 & 0,79 & $* * * /+++$ & $x$ & $* * * /+++$ & 1,68 & $* * *$ & $x$ & $* * * /+++$ \\
\hline V_M1 & PC5 & 1,28 & +++ & $x$ & $* * * /+++$ & 1,68 & non-sign. & $x$ & $* * * /+$ \\
\hline Sten_M/O & diss & & 9 & 10 & $\mathrm{x}$ & & 7 & 10 & $x$ \\
\hline Sten_M/O & PC1 & 3,59 & $* * * /+++$ & $* * * /+++$ & $x$ & 3,52 & $* * *$ & $* * * /+$ & $x$ \\
\hline Sten_M/O & PC2 & 1,06 & $* * *$ & $* * * /+++$ & $x$ & 1,03 & $* * * /+++$ & $* * * /+++$ & $x$ \\
\hline Sten_M/O & PC3 & 2,42 & $* * * /+++$ & $* * * /+++$ & $x$ & 1,39 & $* * *$ & $* * * /+++$ & $x$ \\
\hline Sten_M/O & PC4 & 1,99 & $* * * /+++$ & $* * * /+++$ & $x$ & 0,44 & $* * * /+$ & $* * * /+++$ & $x$ \\
\hline Sten_M/O & PC5 & 0,16 & $* * * /+++$ & $* * * /+++$ & $x$ & 0,80 & $* * *$ & $* * * /+$ & $x$ \\
\hline
\end{tabular}

C

\begin{tabular}{|c|c|c|c|c|c|c|c|c|c|c|c|}
\hline C & & & & PCA_10m & & & & & PCA_30m & & \\
\hline & & $\begin{array}{c}\text { variance } \\
\left(\sigma^{2}\right)\end{array}$ & V_01 & V_02 & V_03 & Sten_M/O & $\begin{array}{c}\text { variance } \\
\left(\sigma^{2}\right)\end{array}$ & V_01 & V_02 & V_03 & Sten_M/O \\
\hline V_01 & diss & & $\mathrm{x}$ & 7 & 4 & 8 & & $x$ & 4 & 0 & 7 \\
\hline v_01 & PC1 & 6,58 & $x$ & $* * * /+++$ & + & $* * * /+++$ & 21,63 & $\mathrm{x}$ & $* * *$ & non-sign. & $* * * /+++$ \\
\hline v_01 & PC2 & 0,57 & $x$ & $* * *$ & non-sign. & non-sign. & 1,55 & $x$ & $* * *$ & non-sign. & $*$ \\
\hline v_01 & PC3 & 1,66 & $x$ & $* * * /+++$ & $* * *$ & $* * * /+++$ & 1,85 & $x$ & non-sign. & non-sign. & $* * *$ \\
\hline v_01 & PC4 & 0,76 & $\mathrm{x}$ & +++ & $*$ & $* /+++$ & 0,41 & $\mathrm{x}$ & $* * *$ & non-sign. & $* * *$ \\
\hline v_01 & PC5 & 0,24 & $x$ & $* * *$ & $* * *$ & $* * * /+$ & 2,78 & $x$ & $* * *$ & non-sign. & $* * * /+++$ \\
\hline v_02 & diss & & 7 & $x$ & 7 & 7 & & 4 & $x$ & 0 & 2 \\
\hline$v_{-}$-02 & PC1 & 2,07 & $* * * /+++$ & $x$ & $* * *$ & $* * * /+$ & 8,94 & $* * *$ & $x$ & non-sign. & non-sign. \\
\hline$v_{-} \_2$ & PC2 & 0,66 & $* * *$ & $x$ & $* * *$ & $* * *$ & 0,82 & $* * *$ & $x$ & non-sign. & $* * *$ \\
\hline v_02 & PC3 & 0,47 & $* * * /+++$ & $x$ & $* * * /+++$ & $* * * /+++$ & 0,58 & non-sign. & $x$ & non-sign. & $* * *$ \\
\hline v_02 & PC4 & 0,10 & +++ & $x$ & $* * * /+$ & +++ & 0,28 & $* * *$ & $x$ & non-sign. & non-sign. \\
\hline v_02 & PC5 & 0,21 & $* * *$ & $x$ & $* * *$ & $* * *$ & 0,55 & $* * *$ & $x$ & non-sign. & non-sign. \\
\hline V_03 & diss & & 4 & 7 & $x$ & 2 & & 0 & 0 & $x$ & 0 \\
\hline
\end{tabular}




\begin{tabular}{|c|c|c|c|c|c|c|c|c|c|c|c|}
\hline V_03 & PC1 & 1,60 & + & $* * *$ & $x$ & non-sign. & 0,56 & non-sign. & non-sign. & $x$ & non-sign. \\
\hline V_O3 & PC2 & 0,24 & non-sign. & $* * *$ & $x$ & non-sign. & 0,39 & non-sign. & non-sign. & $x$ & non-sign. \\
\hline V_O3 & PC3 & 2,81 & $* * *$ & $* * * /+++$ & $x$ & non-sign. & 0,37 & non-sign. & non-sign. & $x$ & non-sign. \\
\hline V_O3 & PC4 & 0,35 & $*$ & $* * * /+$ & $x$ & $* * *$ & 0,32 & non-sign. & non-sign. & $x$ & non-sign. \\
\hline V_O3 & PC5 & 0,16 & $* * *$ & $* * *$ & $x$ & $* * *$ & 0,42 & non-sign. & non-sign. & $x$ & non-sign. \\
\hline Sten_M/O & diss & & 8 & 7 & 2 & $x$ & & 7 & 2 & 0 & $x$ \\
\hline Sten_M/O & PC1 & 3,59 & $* * * /+++$ & $* * * /+$ & non-sign. & $x$ & 3,52 & $* * * /+++$ & non-sign. & non-sign. & $x$ \\
\hline Sten_M/O & PC2 & 1,06 & non-sign. & $* * *$ & non-sign. & $x$ & 1,03 & $*$ & $* * *$ & non-sign. & $x$ \\
\hline Sten_M/O & PC3 & 2,42 & $* * * /+++$ & $* * * /+++$ & non-sign. & $x$ & 1,39 & $* * *$ & $* * *$ & non-sign. & $x$ \\
\hline Sten_M/O & PC4 & 1,99 & $* /+++$ & +++ & $* * *$ & $x$ & 0,44 & $* * *$ & non-sign. & non-sign. & $x$ \\
\hline Sten_M/O & PC5 & 0,16 & $* * * /+$ & $* * *$ & $* * *$ & $x$ & 0,80 & $* * * /+++$ & non-sign. & non-sign. & $x$ \\
\hline
\end{tabular}

1 


\section{Figure 1}

Site locations.

(A) The geographical position of the four sites (Three managed forests and Vorsø) investigated in this paper marked with black stars in the eastern part of Jutland (Denmark). (B) The position of Denmark in Europe (Marked with light edges). (C) The island of Vorsø; V_O1 (6.11 ha); V_O2 (2.65 ha); V_O3 (0.38 ha) (labeled below the zone); V_M1 (15.06 ha); V_M2 (9.09 ha); V_Y2 (5.09 ha); V_Y1 (8.89 ha). (D) The extent of the Tran_Y3 oak (Quercus Robur) forest (4.51 ha). (E) Flø__Y4, the extent of the mixed maple (Acer pseudoplatanus) and beech (Fagus sylvatica) forest ( $0.92 \mathrm{ha}$ ). (F) Sten_M/O, the extent of the predominantly beech (Fagus Sylvatica) forest (20.42 ha). A minor stand of spruce (Picea abies) is recognizable as a dark area in the lower part of the forest. See Fig. 2 for photos of the stands. DDO@Land 2016, Copyright COWI A/S. 

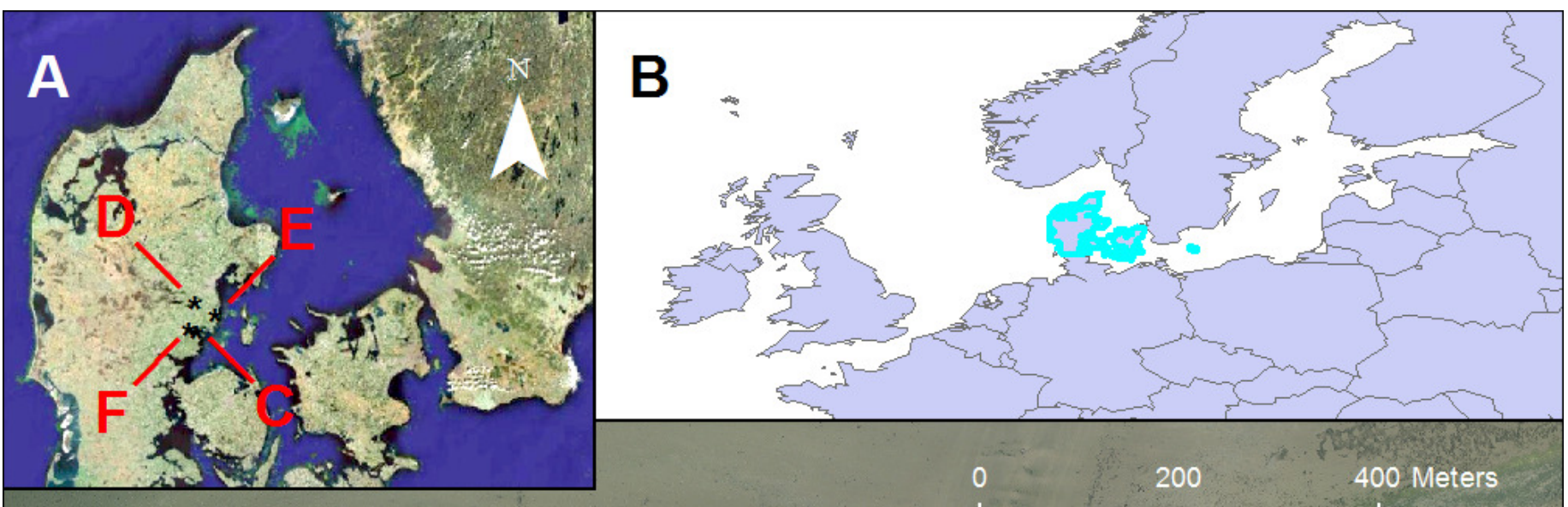

C, Vorsø

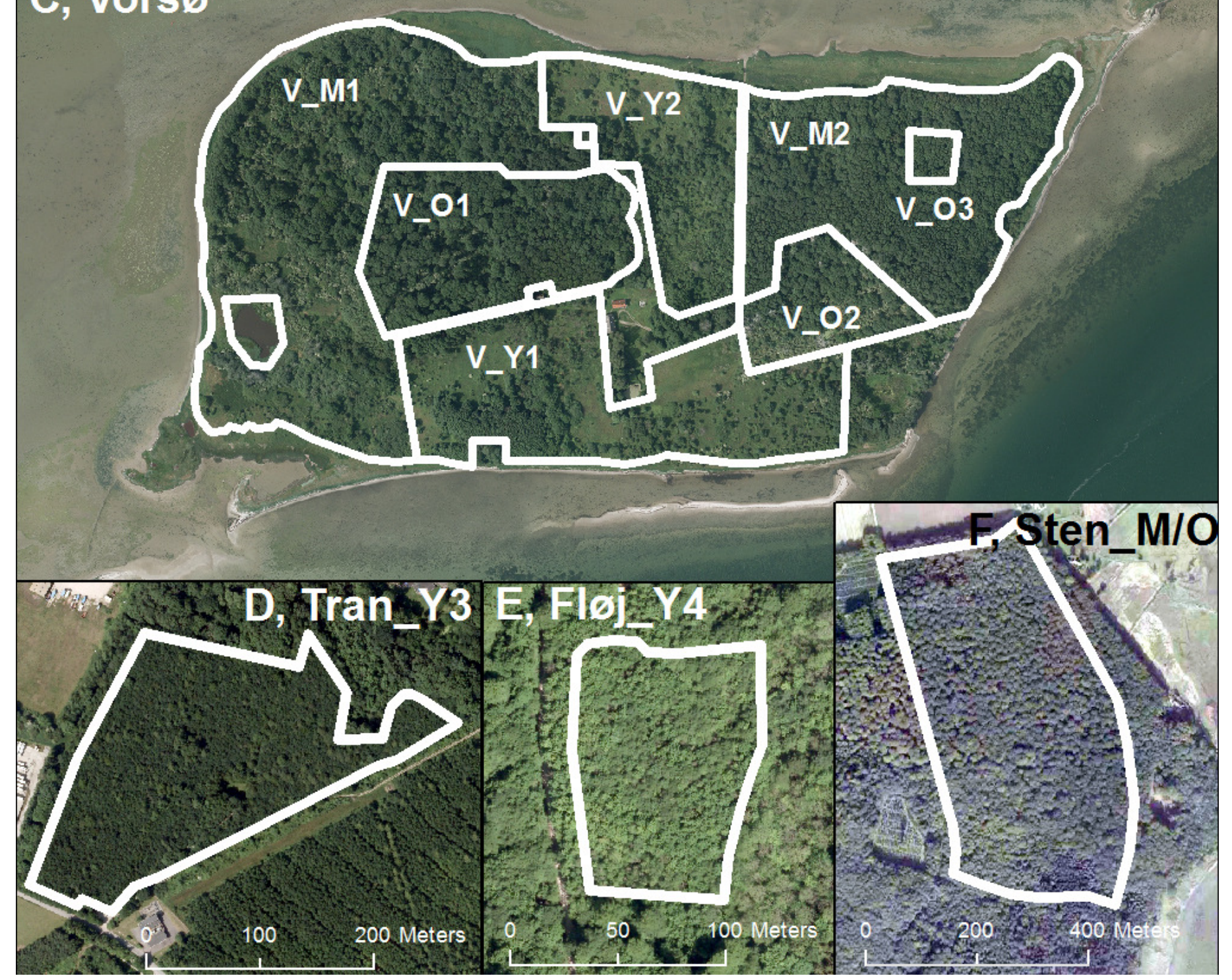




\section{Figure 2}

Photos of the managed stands and selected zones of Vorsø.

(A) A representative site of the managed oak forest of Tran_Y3. (B) A representative site of the managed maple and beech forest of Fløj_Y4. (C) A representative site of the predominated beech forest of Sten_M/O. (D) An example of the homogeneous structure in the sycamore maple (Acer pseudoplatanus) -dominated eastern and southern part of V_M2. Note the structural similarity to the Sten_M/O forest (C). (E) The succession of the otherwise old V_O2 has started over, due to the impact of cormorants (Phalacrocorax carbo), and consists of scattered young trees and shrubs, mainly elderberry (Sambucus nigra). (F) An example of the mixed structure of scrub, gaps, large trees, and dead wood only found in the V_M1. 


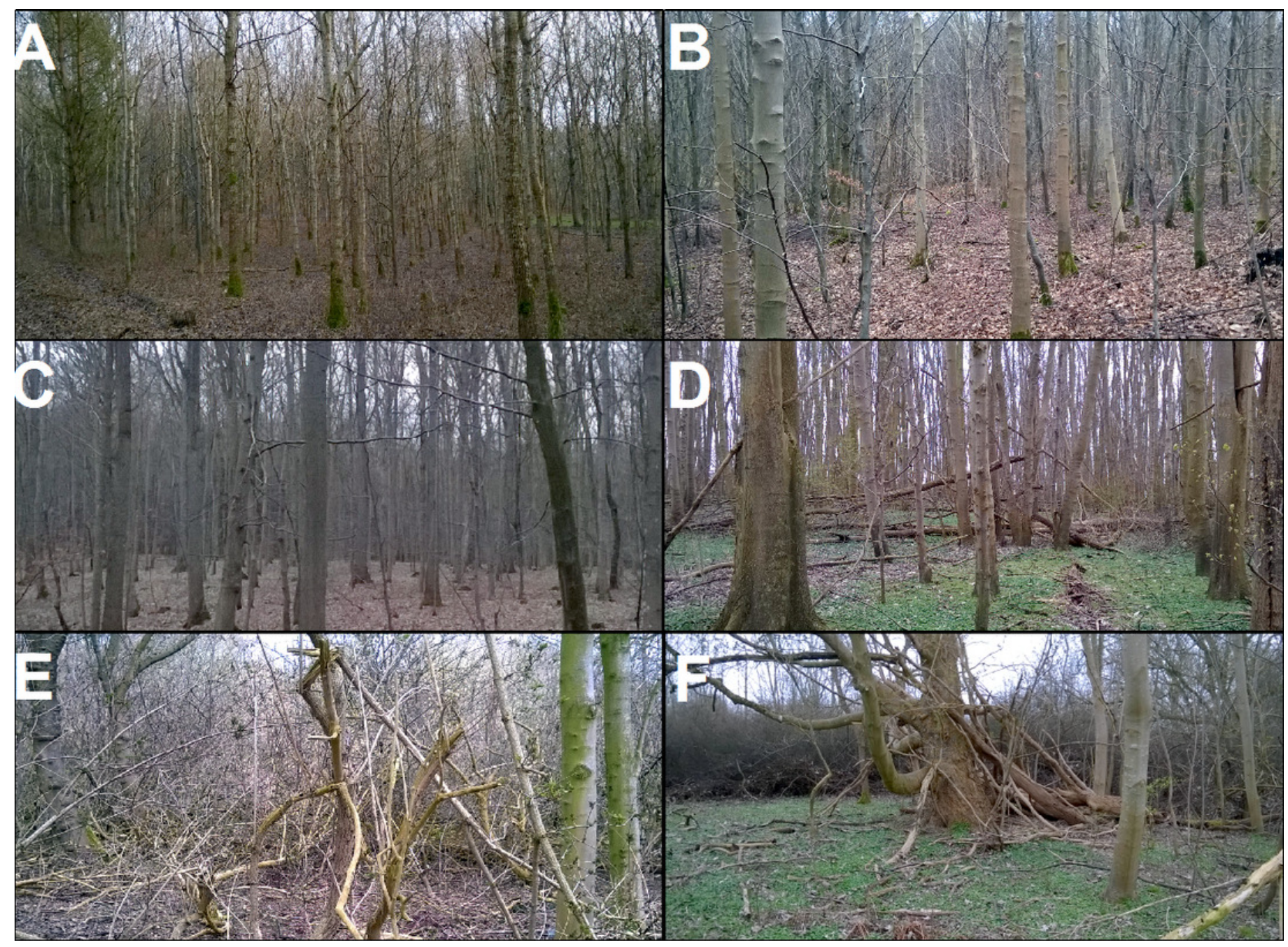




\section{Figure $\mathbf{3}$ (on next page)}

Boxplots of PCA values for PCA_10m and PCA_30m.

A-E: Boxplots of the values of axes 1, 2, 3, 4 and 5 of the PCA_10m and F-J: Boxplots of the values of axes 1, 2, 3, 4 and 5 of the PCA_30m. Number of 10-meter cells in each area in parentheses and number of 30-meter cells in brackets. V_O1 of Vorsø $(n=618)$ [n=73], V_02 of Vorsø $(n=263)$ [ $n=31]$, V_O3 of Vors $\varnothing(n=36)$ [ $n=4]$, Sten_M/O $(n=2041)[n=275]$, V_M2 of Vors $\varnothing(n=912)$ [ $n=120], V_{-} M 1$ of Vors $\varnothing(n=1496)[n=199], V_{-} Y 1$ of Vors $\varnothing(n=511)[n=74]$, V_Y2 of Vorsø $(n=899)$ [ $n=127]$, I, Tran_Y3 $(n=450)[n=79]$ and J, Fløj_Y4 $(n=93)[n=20]$.

There is a rough gradient of age, placing the oldest stands to the left and the youngest to the right. The whiskers mark the minimum and maximum values omitting outliers. 5 and 95 percentiles are marked with dots. Note that the relative variance alternates between the stands and axes, meaning that the gradients (axes) are varying, suited for differentiating specific types of structure. 

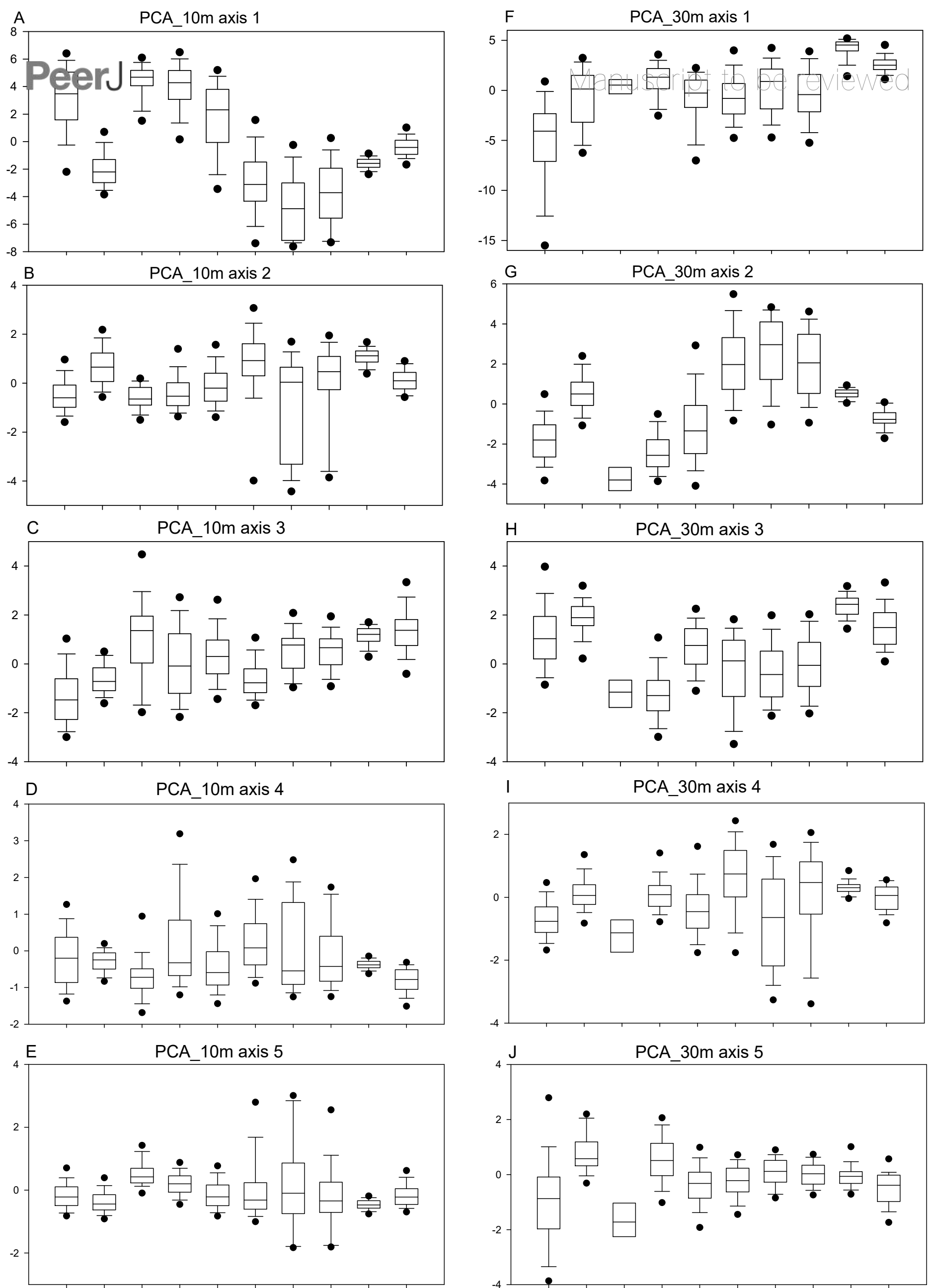

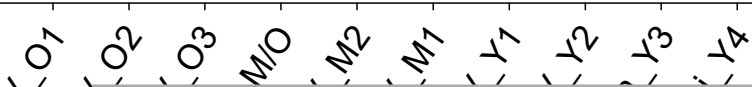

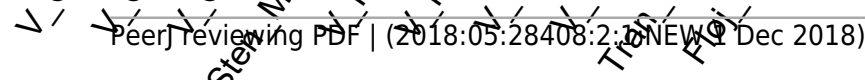

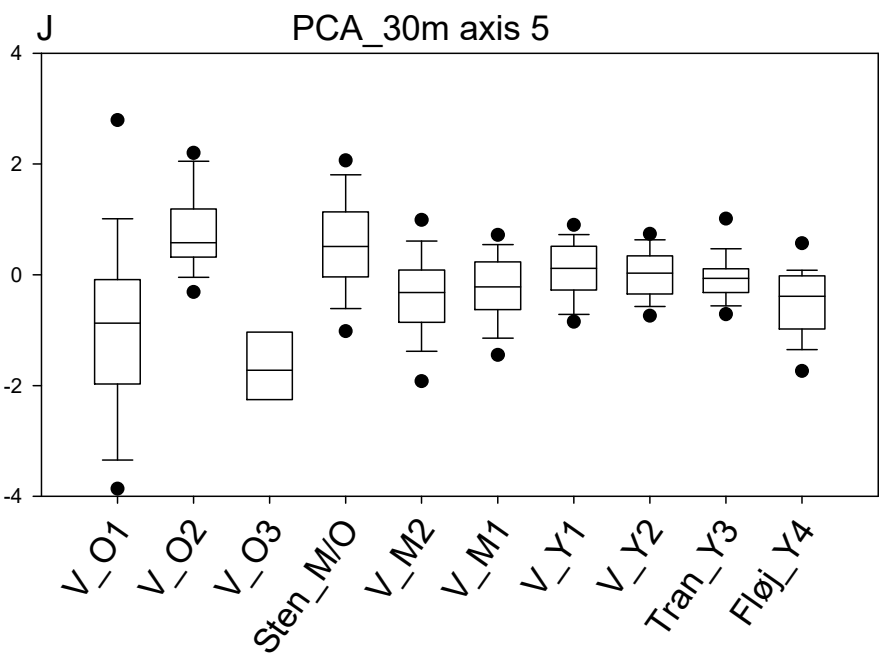




\section{Figure 4}

Maps of PCA values.

A: Values of PCA_10m axis 1, which primarily is a gradient of vegetation height. The highest values are found among the oldest vegetation of $\mathrm{V}_{-} \mathrm{O} 1$ and Sten_M/O, along with the younger stand V_M2, which where rapidly colonized by sycamore maple. Red-colored cells indicate widespread open areas in three of the Vorsø zones. B: Values of PCA_10m axis 5, which is a gradient from bare ground to low and sparse vegetation, subscribing intermediate values to all kinds of taller vegetation. Low values (red) specify the bare ground. Axis 5 is one axis that differentiates the two youngest zones ( $V_{-} Y 1$ and $V_{-} Y 2$ ) on both median and variance, though it is visible that the two former fields contain the same vegetation structural components according to the mapping of axis values. For both A and B: Vorsø zones corresponds to Fig. 1.

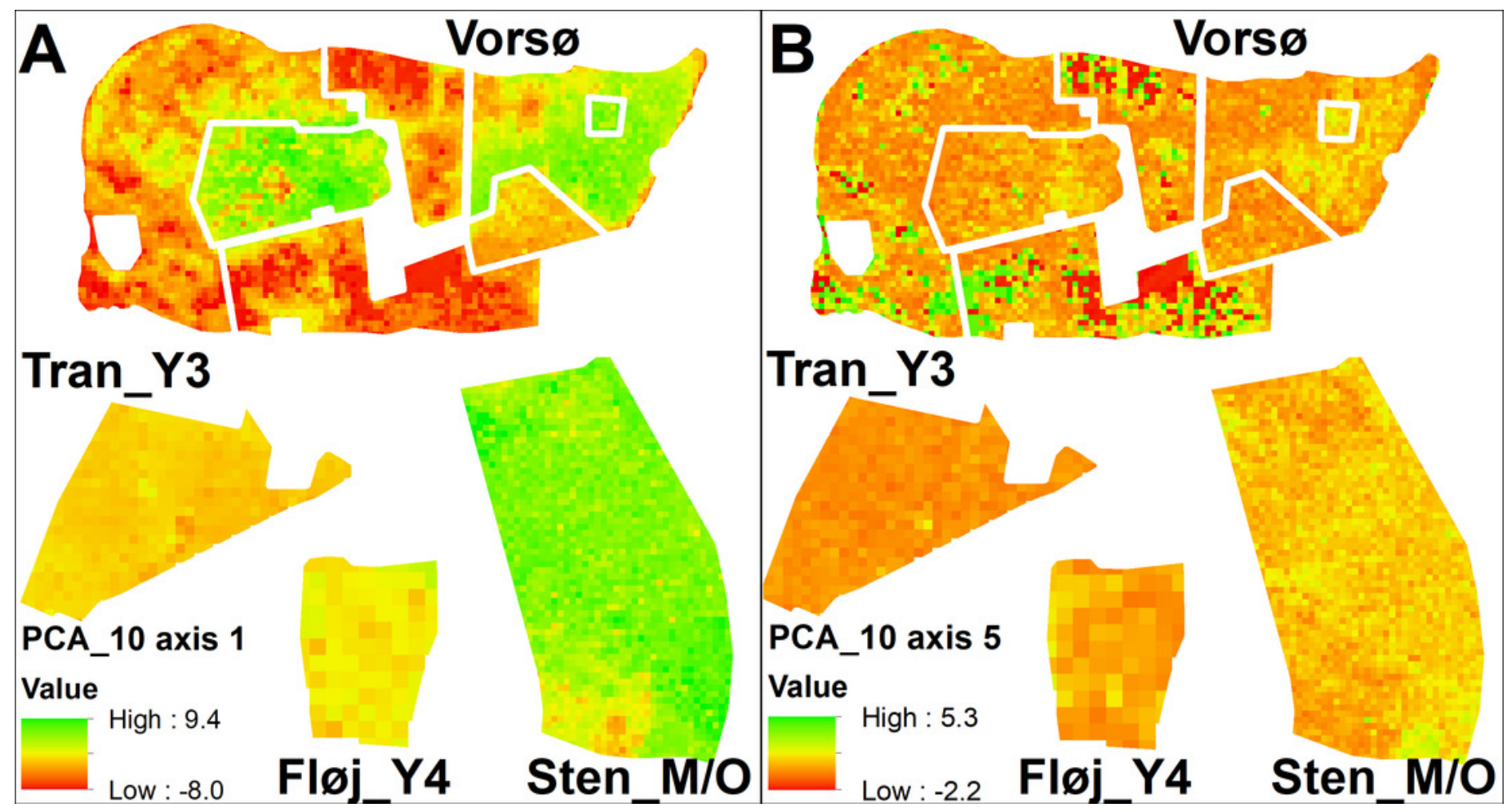

